\title{
Fish crackers development from minced fish and starch: an innovative approach to a traditional product
}

\author{
Biscoito a base de carne mecanicamente separada de pescado e amido: inovação de um \\ produto tradicional
}

\author{
Cristiane Rodrigues Pinheiro NEIVA ${ }^{1,2}$, Thais Moron MACHADO' ${ }^{1}$, Rubia Yuri TOMITA ${ }^{1}$, \\ Érika Fabiane FURLAN ${ }^{1}$, Marildes Josefina LEMOS NETO ${ }^{1}$, Deborah Helena Markowicz BASTOS²*
}

\begin{abstract}
This study aimed to develop sensory acceptable, high nutritional value fish crackers that could be kept at room temperature for 180 days. Minced fish of different low-value species was the raw material employed to produce two types of fish crackers: a) the traditional keropok cracker, which was expanded by deep frying; and b) a low-fat fish cracker, expanded by microwave cooking. The protein content of the fried fish crackers (FFCs) and that of the microwaved fish crackers (MFCs) were high (10.86 and 14.70\%, respectively). The essential amino acid contents of the two types of fish cracker were above the FAO requirements for adults, and the lysine content was above the requirements for children. Sensory analysis, performed by adult panelists, resulted in a general level of acceptability of $90 \%$ for the MFCs and of $97 \%$ for the FFCs. Vacuum packaging maintained microbiological and physicochemical properties for a storage period of 180 days at room temperature. Keywords: minced fish; fish products; fish crackers; nutritional value; acceptability.
\end{abstract}

\section{Resumo}

O objetivo deste trabalho foi o desenvolvimento de um biscoito à base de pescado com alto valor nutricional que pudesse ser estocado em temperatura ambiente por 180 dias. Carne mecanicamente separada (CMS) de pescado de baixo valor econômico foi amatéria-prima utilizada para produzir dois tipos de biscoito de pescado: o biscoito tradicional (keropok), o qual é expandido por fritura em óleo (BF), e um biscoito expandido em micro-ondas, com baixo teor de lipídios (BMO). O conteúdo de proteínas do BF e o do BMO é alto para este tipo de produto $(10,86$ e 14,70\%, respectivamente). Ambos os biscoitos apresentaram teores de aminoácidos essenciais acima do recomendado pela FAO para adultos, sendo o conteúdo de lisina maior do que o recomendado para crianças. A análise sensorial realizada por provadores adultos mostrou alto nível de aceitação dos biscoitos (90\% para o BMO e $97 \%$ para o BF). A estocagem em embalagem a vácuo permitiu que o produto mantivesse a qualidade microbiológica e propriedades físico-químicas por 180 dias em temperatura ambiente.

Palavras-chave: peixe; carne mecanicamente separada; biscoito de pescado; valor nutricional; aceitabilidade.

\section{Introduction}

One of the recommended strategies to improve dietary quality in face of the current worldwide epidemics of obesity and chronic noncommunicable diseases is to increase the consumption of fish. In general, fish is a high-protein, lowcalorie food and an important source of omega-3 fatty acids and minerals, such as calcium and phosphorus.

In order to increase fish consumption, strategies are required to overcome or bypass certain limitations of commercialization and acceptability of fish, which include the cold chain distribution process and the presence of bones.

A key element to increase fish consumption is to provide processed and manufactured fish products preserving the high nutritional value of fish and meeting customer expectations (sensory attributes).

Fish crackers, known as keropok, are a very popular delicacy in Malaysia and other Asian countries (YU et al., 1981;
SIAW et al., 1985; YU; TAN, 1990; YU; LOW, 1992). Keropok is traditionally produced by means of starch gelatinization, which is achieved through steaming. Keropok is made by forming a dough from a mixture of starch, comminuted fish, salt, sugar, monosodium glutamate, and water. Before consumption, the dough is sliced, and the slices are fried in hot oil, which causes keropok to expand into a porous, low-density product (KYAW et al.,1999). The effects of process parameters, as well as of the type and amount of starch, on the linear expansion and crunchiness of keropok after frying have previously been described (CHEOW et al., 2004; KYAW et al., 1999; KYAW et al., 2001b; MOHAMED et al., 1989).

The production of minced fish is a well-established process that allows rational use of fishery by-products and low-value fish species. When good manufacture practices are observed and the fish used is of high quality, the product is boneless and has no smell or pigments, which makes it suitable for use in various

Received 14/5/2010

Accepted 4/9/2010 (004838)

${ }^{1}$ Fish Technology Laboratory, Fisheries Institute, São Paulo State Agency for Agribusines Technology, Santos, SP, Brazil

2 Nutrition Department, School of Public Health, São Paulo University - USP, Av. Dr. Arnaldo, 715, CEP 01246-904, São Paulo, SP, Brazil, e-mail: dmbastos@usp.br

${ }^{*}$ Corresponding author 
food products. Minced fish manufactured in a hygienic manner has the same initial quality as the raw material from which it was made. Existing uses for minced fish are the manufacture of fish flour, fish cakes, fish fingers, surimi, and kamaboko (FOOD..., 2010).

Based on the fact that wheat crackers have a global impact on nutrition and that variations of this product are well accepted (CHEOW et al., 2004; SALLEH et al., 2007; SINGHAL et al., 2008; SUBBA, 2002), we believe that the development of sensory acceptable fish crackers of high nutritional quality can be a successful strategy for increasing fish consumption and that fish crackers can be an alternative to high-calorie, low-nutritionalvalue, ready-to-eat food.

The aims of this work were to develop fish crackers from minced fish of low-value species introducing an innovative procedure for expanding the product in order to maintain its nutritional value; to determine the crackers nutritional composition and the sensory attributes as well as to evaluate the product stability during a storage period of 180 days at room temperature.

\section{Material and methods}

\subsection{Minced fish and fish cracker development}

Minced fish was produced from Southern King Croaker (betara) (Menticirrhus americanus) and Sand Drum (castanha) (Umbrina coroides), low-value fish species from the Brazilian coast. One hundred and twenty kilograms, corresponding to $50 \%$ of each fish species, were collected in Santos, São Paulo, Brazil. According to the "Sistema Gerenciador de Banco de Dados de Controle Estatístico de Produção Pesqueira Marítima ProPesq" (a system for data bank processing and statistic control of the marine fishery Production) these species accounted for $5.5 \%$ of the total of species/categories of fish unloaded in São Paulo from 2000-2004 (ÁVILA-DA-SILVA et al., 2005).

Fish were decapitated, gutted, and submitted to a mechanical process to obtain the minced fish as described by FAO (FOOD..., 2010). Briefly, fish were gutted and headed and than fed into the separator (Bibun, model SDX-13) from a hopper to pass between a moving rubber belt and the outside of a revolving perforated drum of stainless steel. The flesh was forced through the perforations into the drum from where it was expelled as a coarse mince by a fixed screw. Skin and bone were retained on the outside of the drum and removed continuously by a scraper blade. The drum perforations were $5 \mathrm{~mm}$ in diameter and the tension on the belt was within the medium range.

Fish crackers were prepared according to Siaw et al. (1985). A dough-like mixture was produced by mixing minced fish to cassava starch $(50: 50 \mathrm{w} / \mathrm{w})$ and then, $1.5 \%$ salt, $1.5 \%$ monosodium glutamate, $1 \%$ sugar and $20 \%$ water were incorporated to the mixture. The dough-like mixture was then stuffed into cellulose synthetic casings and submitted to cooking with direct steam at $100{ }^{\circ} \mathrm{C}$, at atmospheric pressure, in order to allow gel development. After steaming, cooked gels were immersed in iced water and chilled $\left(4-7^{\circ} \mathrm{C}\right)$ for 12 hours, after which they were sliced into $2 \mathrm{~mm}$ thick slices. The slices were then dried in an oven at $50{ }^{\circ} \mathrm{C}$ for 12 hours. The dried non-expanded crackers slices were either deep fried in soybean oil at $180-190^{\circ} \mathrm{C}$ for 30 seconds or baked in a microwave oven inside a "popcorn type" packaging for 60 seconds, replacing the use of deep frying to expand the slices (Figure 1).

\subsection{Chemical composition}

Fried fish crackers (FFCs) and micro-oven baked crackers (MFCs) proximate composition were determined as described in the official methods (ASSOCIATION..., 1995). Protein content was determined by micro-Kjeldahl method $(\mathrm{N} \times 6.25)$; weight loss to a final constant weight was recorded as moisture content in an oven at $105^{\circ} \mathrm{C}$; ash content was determined by incineration in a muffle furnace at $550^{\circ} \mathrm{C}$; lipid was determined by cold extraction, according to Bligh and Dyer (1959); carbohydrate was determined by difference [100 - (moisture content + protein content + lipid content + ash content)]. Energy was determined using Atwater factors (Equation 1):

$E=(9 \times$ Fat content $)+(4 \times$ Protein content $)+(4 \times$ Carbohydrate content $)(1)$

Fatty acid profiles were determined after transesterification of the lipid fraction according to IUPAC 2301 / method 344/ IV. Methyl esters were analyzed in a Shimadzu GC-2010 gas chromatograph equipped with flame ionization detector. The compounds were separated in fused silica capillary column with the stationary phase of $100 \mathrm{~cm}$ bis-cyanipropyl polysiloxane with $0.25 \mathrm{~mm}$ in inner diameter and $0.20 \mu \mathrm{m}$ in film thickness (Supelco - SP 2560). The operation conditions were as follows: programmed column temperature: $140^{\circ} \mathrm{C}$ (5 minutes), heating rate of $4{ }^{\circ} \mathrm{C} /$ minutes until $240{ }^{\circ} \mathrm{C}$ (10 minutes), injector temperature of $250^{\circ} \mathrm{C}$; detector temperature of $260^{\circ} \mathrm{C}$; carrier gas: hydrogen; carrier gas linear speed of $34 \mathrm{~cm} /$ seconds; and sample division ratio 1:50.The identification of the fatty acids was achieved by comparing their retention times with those of the fatty acid methyl ester mixture (FAME 37, 47885, Sigma Chemical Co). The results are expressed as relative percentage.

(1) Minced fish + cassava starch + seasonings

Steaming $100^{\circ} \mathrm{C} / 15 \mathrm{~m}$

12 hous $/ 4{ }^{\circ} \mathrm{C}$ (gel development)

(2) Gel-like dough

Drying in oven $50^{\circ} \mathrm{C} / 12$ hous

(3) Dried non-expanded fish cracker

Deed frying $180^{\circ} \mathrm{C} / 30$ seconds or Micro-oven baking

("popcorn type" packaging for 60 seconds)

(4) Expanded fish cracker

Figure 1. Fish crackers production fluxogram highlighting the analysis performed in steps (3) and (4). 
The dried non-expanded crackers (before expansion) were analyzed for the amino acid profile by acid hydrolysis using Pierce reference solution of amino acids, according to Spackaman (1958). Tryptophan was analyzed according to Spies (1967).

\subsection{Chemical and microbiological stability evaluation}

The dried non-expanded fish crackers were stored in a coextruded aluminum package with 5 layers based onpolyethylene/adhesive/polyamide, at room temperature $\left(25 \pm 2{ }^{\circ} \mathrm{C}\right)$ and evaluated after 1 (one), 90 , and 180 days of storage $\left(\mathrm{T}_{\mathrm{o}}, \mathrm{T}_{1}\right.$, and $\mathrm{T}_{2}$ respectively). Thiobarbituric acid reactive substances (TBARS) and total volatile base nitrogen (TVBN) were used as parameters of chemical stability, since they measure undesirable chemical changes. Water activity (Aw) was measured using the Aqualab Series equipment (Pullman, WA). The $\mathrm{pH}$ was determined with a Tecnal brand potentiometer. TBARs analysis was performed according to Tarladgis et al. (1960) and TVBN following the method described elsewhere (ANTONACOPOULOS; VYNCKE, 1989).

The presence of Salmonella, S. aureus and sulfite reducing clostridia was determined at $\mathrm{T}$ Total aerobic mesophyll, total and fecal coliforms (E. coli) as well as mold and yeast counts were determined at $\mathrm{T}_{1}$ and $\mathrm{T}_{2}$, according to Downes and Ito (2001).

\subsection{Determination of the linear expansion of fish crackers}

The percentage linear expansion of fish crackers was determined by measuring five lines traced transversally over each dried fish cracker slice, before and after either baking or frying. The length of each line was individually measured randomly with a ruler and replicated 10 times, according to Yu et al.(1981).

The linear expansion of a cracker is characterized as a measurement of textural quality and can be calculated by the Equation 2:

$L E=100(L f-L o) L o^{-1}$

where Lo and Lf are the lengths of the lines (in $\mathrm{cm}$ ) before and after the expansion of the fried or baked fish cracker, respectively.

\subsection{Sensory analysis}

Forty untrained panelists (aged 19-65 years) evaluated the fish crackers in relation to color, flavor, crunchiness, and general acceptability using a nine-point hedonic scale varying from "dislike extremely" to "like extremely", according to Stone and Sidel (1993). Fish cracker samples were presented at room temperature in private booths under white lighting.

\subsection{Data analysis}

Analysis of Variance (ANOVA) and mean scores were compared using Tukey's (HSD) test or Student t-test depending on the number of analyzed groups.

\subsection{Ethical aspects}

This research was approved by the School of Public Health - São Paulo University Ethics Committee (protocol 1834/2006).

\section{Results and discussion}

\subsection{Nutritional composition}

The mean nutrient content and the mean energy content of the microwaved fish crackers (MFCs) and those of the fried fish crackers (FFCs) are depicted in Table 1.

The mean protein content of the MFCs was $14.70 \%$, and the mean protein content of the FFCs was $10.86 \%$. According to the Codex Alimentarius (CODEX..., 2001), crackers are classified as grade I when the protein content is above $12 \%$. Therefore, the MFCs produced in the present study can be considered a good source of protein.

As expected, the lipid content of the FFCs was higher than that of the MFCs (26.11 vs. $0.42 \%$ respectively). The calorie content of the FFCs was, therefore, $65 \%$ greater than that of the MFCs. Since the consumption of high-calorie food is a risk factor for obesity among children and young adults, the consumption of and/or development of products that are not deep fried can be considered an adjuvant strategy to reduce the increasing rate of obesity and associated pathologies.

The essential amino acid content of the fish crackers produced in the present study was above the FAO requirements for essential amino acids for adults and met the FAO requirements for threonine, valine, isoleucine, leucine, tryptophan and, more importantly, lysine (a limiting amino acid in cereals and flours) for children (FOOD..., 1990; 1985) (Table 2). Various studies have reported that, in developing countries, lysine intake is below the requirements for children. Therefore, the development of products that are rich in lysine, such as crackers - a food product that is consumed worldwide might be a successful strategy for providing healthy, low-calorie food products containing high biological value protein.

The monounsaturated fatty acid content of the FFCs was higher than that of the MFCs (24.47\% vs. 20.54\%) (Table 3). Likewise, the polyunsaturated fatty acid (PUFA) content of the FFCs was higher than that of the MFCs $(61.09 \%$ vs. 43.77\%). Long-chain PUFAs (C 20:4, C 20:5 and C 22:6) were

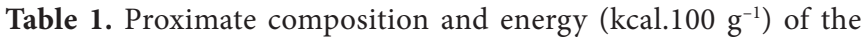
microwaved (MFCs) and fried (FFCs) crackers*.

\begin{tabular}{lcc}
\hline & $\begin{array}{c}\text { Microwaved fish crackers } \\
\text { MFCs }\end{array}$ & $\begin{array}{c}\text { Fried fish crackers } \\
\text { FFCs }\end{array}$ \\
\hline Moisture (\%) & $3.12^{\mathrm{c}} \pm 0.15$ & $0.48^{\mathrm{d}} \pm 0.06$ \\
Protein (\%) & $14.70^{\mathrm{a}} \pm 0.37$ & $10.86^{\mathrm{c}} \pm 0.26$ \\
Lipids (\%) & $0.42^{\mathrm{a}} \pm 0.07$ & $26.11^{\mathrm{b}} \pm 0.54$ \\
Ash (\%) & $3.58^{\mathrm{c}} \pm 0.06$ & $2.64^{\mathrm{d}} \pm 0.12$ \\
Carbohydrates (\%) & $78.18^{\mathrm{c}}$ & $59.91^{\mathrm{d}}$ \\
Energy & $375.30^{\mathrm{c}}$ & $518.07^{\mathrm{d}}$ \\
\hline
\end{tabular}

${ }^{*}$ Mean \pm standard deviation of three replicates. The different superscripts in the lines denote significant differences $(\mathrm{p}<0.05)$. 
Table 2. Amino acid composition of the non-expanded fish crackers ${ }^{*}$.

\begin{tabular}{|c|c|c|c|}
\hline Amino acid & $\begin{array}{c}\text { Dried } \\
\text { non-expanded } \\
\text { fish cracker }\end{array}$ & EAA-children ${ }^{* *}$ & EAA-adults ${ }^{* * *}$ \\
\hline Aspartic Acid & $120.00 \pm 0.00$ & & \\
\hline Threonine $€$ & $48.33 \pm 0.02$ & 34 & 9 \\
\hline Serine & $42.50 \pm 0.06$ & & \\
\hline Glutamine Acid & $303.33 \pm 0.01$ & & \\
\hline Proline & $40.00 \pm 0.06$ & & \\
\hline Glycine & $54.17 \pm 0.01$ & & \\
\hline Alanine & $65.00 \pm 0.03$ & & \\
\hline Valine $€$ & $47.50 \pm 0.06$ & 35 & 13 \\
\hline $\begin{array}{l}\text { Methionine + } \\
\text { Cysteine } €\end{array}$ & $20.84 \pm 0.02$ & 25 & 17 \\
\hline Isoleucine $€$ & $44.17 \pm 0.06$ & 28 & 13 \\
\hline Leucine $€$ & $83.33 \pm 0.03$ & 66 & 19 \\
\hline $\begin{array}{l}\text { Phenhlalanine + } \\
\text { Tyrosine } €\end{array}$ & $52.50 \pm 0.04$ & 63 & 19 \\
\hline Lysine $€$ & $104.17 \pm 0.08$ & 58 & 16 \\
\hline Histidine $€$ & $18.33 \pm 0.04$ & & 16 \\
\hline Arginine $€$ & $55.83 \pm 0.05$ & & \\
\hline Tryptophan $€$ & $12.50 \pm 0.01$ & 11 & 5 \\
\hline TEAA & 462.50 & & \\
\hline TAA & 1128 & & \\
\hline TEAA/TAA (\%) & 41 & & \\
\hline
\end{tabular}

Table 3. Fatty acids (\% relative area) in fried and microwaved fish crackers.

\begin{tabular}{lcc}
\hline \multicolumn{1}{c}{ Fatty acids } & $\begin{array}{c}\text { Fried fish } \\
\text { crackers }\end{array}$ & $\begin{array}{c}\text { Microwaved fish } \\
\text { crackers }\end{array}$ \\
\hline C14:0 (Myristic) & $\mathrm{ND}$ & $\mathrm{ND}$ \\
C15:0 ( Pentadecanoic) & $\mathrm{ND}$ & $\mathrm{ND}$ \\
C16:0 (Palmitic) & 10.92 & 26.29 \\
C17:0 (Heptadecanoic) & $\mathrm{ND}$ & $\mathrm{ND}$ \\
C18:0 (Stearic) & 3.14 & 9.27 \\
C22:0 (Behenic) & $\mathrm{ND}$ & $\mathrm{ND}$ \\
Total saturated (TS) & $\mathbf{1 4 . 5 8}$ & $\mathbf{3 5 . 5 6}$ \\
C16:1n7 (Palmitoleic) & $\mathrm{ND}$ & 6.81 \\
C18:1n9 (Oleic) & 24.47 & 13.73 \\
Total monounsaturated (TMS) & $\mathbf{2 4 . 4 7}$ & $\mathbf{2 0 . 5 4}$ \\
C18:2n6 (Linoleic) & 55.24 & 9.55 \\
C18:3n3 (Linolenic) & 5.47 & $\mathrm{ND}$ \\
C20:4n6 (Araquidonic) & $\mathrm{ND}$ & 6.68 \\
C20:5n3 - EPA & $\mathrm{ND}$ & 6.54 \\
C22:6n3 - DHA & $\mathrm{ND}$ & 21.0 \\
Total polyunsaturated (TPI) & $\mathbf{6 1 . 0 9}$ & $\mathbf{4 3 . 7 7}$ \\
Total omega 3 & $\mathbf{5 . 4 7}$ & $\mathbf{2 7 . 5 4}$ \\
Total omega 6 & $\mathbf{5 5 . 6 2}$ & $\mathbf{1 6 . 2 3}$ \\
TPI/TS & $\mathbf{4 . 1 9}$ & $\mathbf{1 . 2 3}$ \\
\hline
\end{tabular}

$\mathrm{ND}=$ not detect; TS = total saturated fatty acids; TMS = total monounsaturated fatty acids; TPI $=$ total polyunsaturated fatty acids. detected only in the MFCs, and linoleic acid was the most abundant PUFA in the FFCs (55.24\%). It is well known that an imbalance between omega- 6 fatty acid intake and omega-3 fatty acid intake can affect the inflammatory process and that the excess of omega- 6 is detrimental to health. The presence of abundant levels of omega- 3 fatty acids in fish and fish products can significantly encourage the consumption of such foods due to the beneficial effects of omega- 3 fatty acids on health (ANDERSON; CONNOR, 1989; SIMOPOULOS et al., 1999; KRIS-ETHERTON et al., 2003; LEVITAN et al. 2009; BJERREGAARD et al., 2010).

Foods in which the PUFA/saturated fatty acid (SFA) ratio is higher than 0.45 are recommended for the prevention of cardiovascular disease. In the present study, both FFCs and MFCs showed excellent PUFA/SFA ratios (4.2 and 1.2, respectively).

Considering the fatty acid profile and lipid content of the two types of fish crackers evaluated, the MFCs is in accordance with the nutritional requirements regarding the lipid intake: low lipid content and high long-chain PUFA content.

\subsection{Objective evaluation and sensory evaluation: linear expansion and acceptability}

One of the most important sensory attributes of crackers is crispness, which, according to Vincent $(1998$, p. 162) can be defined as

[...] the rate at which the force applied by the jaw adductors (the closing muscles) drops when the material fractures, together with the sensing of a reduction in pressure on individual teeth. Crispness may be associated with a rapid drop in force, which is associated with rapid propagation of fracture which, in turn, necessitates that the material is brittle.

Crispness can be affected by the nature of the material and the structure that the material forms.

The crispness of fish crackers can be determined by evaluating linear expansion. Linear expansion results from the rapid evaporation of water and consequent expansion of starch granules and vacuoles, which occur when the crackers are exposed to high temperatures (CHEOW et al.,1999b; CHEOW et al.,2004; KYAW et al.,1999; KYAW et al., 2001; KYAW et al., 2001a). Keropok is traditionally expanded by deep frying in oil. This procedure enhances the sensory attributes of fish crackers; however, it increases the lipid and calorie contents, which is prejudicial to the nutritional value of the crackers. Extrusion cooking can be an alternative for expanding the fish starch dough (KYAW et al., 2001a; SHAH et al., 1999; YU et al., 1981). Another alternative, which is proposed in the present study, is the use of popcorntype packages and microwave baking. The main advantage of microwave cooking over extrusion cooking is that the consumer can expand the product (which mimics the traditional keropok) at home.

The fish crackers that were produced in the present study showed high linear expansion rates (Figure 2), which were lower than the rates reported by Tongdang et al. (2008) (160-190\%) 
but similar to the rates reported by Kyaw et al. (1999) (95-125\%) and higher than the rates reported by King (2002) (79.2\%). According to Siaw et al. (1985), the linear expansion rate must be higher than $77 \%$ for an acceptable level of crispness.

In the present study, linear expansion varied greatly among crackers regardless of the type of heat treatment (deep frying or microwave baking) indicating that heat distribution was not uniform in either treatment. There was no significant difference between the two types of treatment in terms of linear expansion $(p=0.6)$ although MFCs showed higher expansion rate values than those of FFCs. Linear expansion can be optimized by combining temperature, time of exposure to the temperature, and final moisture (VASANTI NAIR et al., 1996). Other important factors that affect expansion are the following: the fish/starch ratio; the gel strength of the dough formed during the steaming stage; and the protein content, which affects gel formation and strength and, therefore interferes with vacuole formation/degradation during water evaporation (BADRIE; MELLOWES, 1992).

Although the linear expansion rate can predict the crispness of crackers, it does not preclude the need for sensory evaluation by consumers. In order to determine the acceptability of FFCs and MFCs, these products were evaluated by a panel of 40 volunteers in terms of color, crispness, flavor and general acceptability.

The FFCs had higher scores for all sensory attributes than those of MFCs (Table 4). With regard to the MFCs, color was the attribute that received the lowest score (6.4), which was probably due to the fact that the MFCs were paler than the FFCs. The distribution of scores for general acceptability (Figure 3) revealed that both products were perceived as sensory acceptable since the FFCs and the MFCs received, respectively, 97 and $90 \%$ of grades ranging from 6 (liked it a little) to 9 (liked it very much). Of the total panelists, $75 \%$ preferred the FFCs and $100 \%$ stated that they would purchase both the fried and the baked crackers.

\subsection{Stability of fish cracker before expansion}

The chemical stability and microbiological safety of the dried non-expanded fish crackers (the marketable product) were evaluated during a storage period of 180 days at room temperature using appropriate packaging material.

There were no significant differences between the initial values and those observed at the end of the storage period in terms of $\mathrm{pH}$ and $\mathrm{Aw}(\mathrm{p}>0.05)$ (Table 5), while the TBARs value was slight lower at the end of the storage period. The concentration of TBARS is widely used as an indicator of the degree of lipid oxidation. However, the TBARs methodology lacks specificity since thiobarbituric acid can react with several different carbonyl compounds, which may explain the observed difference.

There was a significant increase in the levels of total volatile base nitrogen (TVBN) after 90 days at room temperature (from 1.54 to $\left.18.16 \mathrm{mg} \mathrm{N} 100 \mathrm{~g} \mathrm{~g}^{-1}\right)$. The value observed after a storage period of 90 days $\left(18.16 \mathrm{mg} \mathrm{N} .100 \mathrm{~g}^{-1}\right.$ ) was not significantly

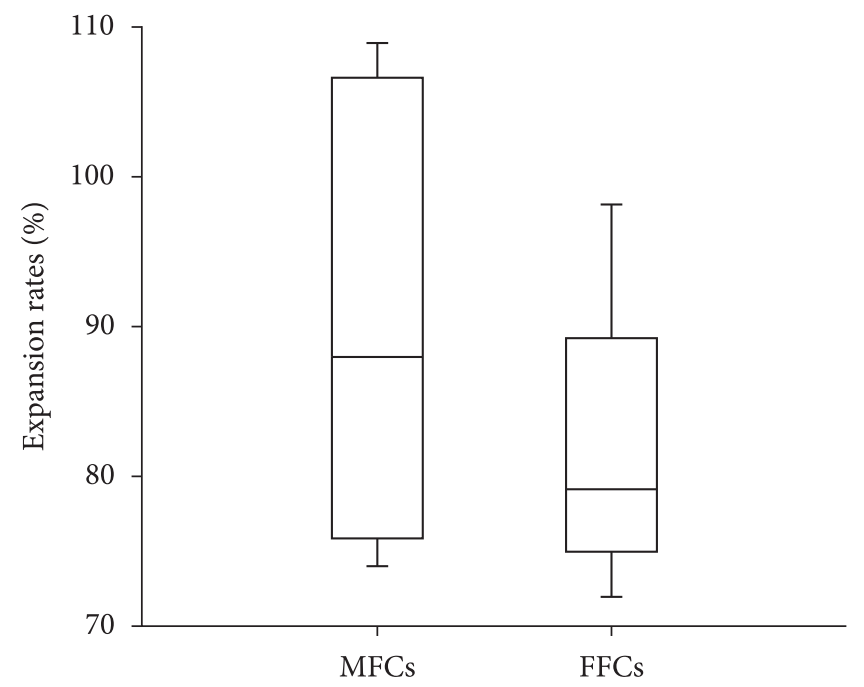

Figure 2. Linear expansion of the microwaved (MFCs) and fried (FFCs) fish crackers.

Table 4. Mean sensory scores for microwaved and fried fish crackers.

\begin{tabular}{lcc}
\hline & Microwaved fish crackers & Fried fish crackers \\
\hline Color & $6.4^{\mathrm{a}}$ & $7.08^{\mathrm{b}}$ \\
Crunchiness & $7.73^{\mathrm{a}}$ & $8.43^{\mathrm{b}}$ \\
Flavor & $7.20^{\mathrm{a}}$ & $7.93^{\mathrm{b}}$ \\
General acceptance & $7.08^{\mathrm{a}}$ & $7.95^{\mathrm{b}}$ \\
\hline
\end{tabular}

The different superscripts in the lines denote significant differences $(\mathrm{p}<0.05)$.

Table 5. Non-expanded fish cracker physicochemical parameters related to stability during storage*.

\begin{tabular}{lccc}
\hline \multirow{2}{*}{ Parameters } & \multicolumn{3}{c}{ Non-expanded fish crackers } \\
\cline { 2 - 4 } & To & $\mathrm{T}_{1}$ & $\mathrm{~T}_{2}$ \\
\hline $\mathrm{pH}$ & $6.88^{\mathrm{a}} \pm 0.01$ & $6.90^{\mathrm{a}} \pm 0.01$ & $6.87^{\mathrm{a}} \pm 0.04$ \\
$\mathrm{Aw}$ & $0.36^{\mathrm{a}}$ & $0.36^{\mathrm{a}}$ & $0.36^{\mathrm{a}}$ \\
TVB-N (mg N.100g & $1.54^{\mathrm{a}} \pm 0.00$ & $18.16^{\mathrm{b}} \pm 1.57$ & $17.25^{\mathrm{b}} \pm 1.57$ \\
TBARs (mg MDA.kg & $1.41^{\mathrm{a}} \pm 0.14$ & $1.38^{\mathrm{a}} \pm 0.31$ & $1.19^{\mathrm{b}} \pm 0.17$ \\
\hline
\end{tabular}

${ }^{*}$ Mean \pm standard deviation of three replicates. The different superscripts in the lines denote significant differences $(\mathrm{p}<0.05) \cdot \mathrm{T}_{0}=1$ day after processing, $\mathrm{T}_{1}=90$ days after processing, $\mathrm{T}_{2}=180$ days after processing. TVB-N $=$ Total volatile base nitrogen. TBARs $=$ Thiobarbitric acid reactive substances. $\mathrm{MDA}=$ Malondialdehyde.

Table 6. Fish cracker microbiological indicators during storage.

\begin{tabular}{lccc}
\hline \multirow{2}{*}{ Microbiological indicator } & \multicolumn{3}{c}{ Non-expanded fish crackers } \\
\cline { 2 - 4 } & $\mathrm{To}$ & $\mathrm{T}_{1}$ & $\mathrm{~T}_{2}$ \\
\hline Salmonella $($ in $25 \mathrm{~g}$ ) & absent & $\mathrm{NP}$ & $\mathrm{NP}$ \\
Total coliforms $\left(\mathrm{MPN} \cdot \mathrm{g}^{-1}\right)^{*}$ & $<10$ & 4 & $<3$ \\
Escherichia coli $\left(\mathrm{MPN} \cdot \mathrm{g}^{-1}\right)^{*}$ & $<10$ & $<3$ & $<3$ \\
Staphylococcus aureus $\left(\mathrm{CFU} \cdot \mathrm{g}^{-1}\right)^{* *}$ & $<10^{2}$ & $\mathrm{NP}$ & $\mathrm{NP}$ \\
Sulfite reducing clostridia $\left(\mathrm{CFU} \cdot \mathrm{g}^{-1}\right)^{* *}$ & $<10$ & $\mathrm{NP}$ & $\mathrm{NP}$ \\
Mold and yeast count $\left(\mathrm{CFU} \cdot \mathrm{g}^{-1}\right)^{* *}$ & $<10^{2}$ & $<10^{2}$ & $<10^{2}$ \\
Total count of aerobic mesophyll & $\mathrm{ND}$ & $3.0 \times 10^{3}$ & $2.2 \times 10$ \\
$($ CFU.g & & & \\
\hline${ }^{*}$ Most probable number. & ${ }^{* *}$ Colony Forming Units per gram. ND - not determined. \\
$\mathrm{T}_{\mathrm{o}}=1$ day after processing. $\mathrm{T}_{1}=90$ days after processing. $\mathrm{T}_{2}=180$ days after processing.
\end{tabular}

different $(\mathrm{p}>0.05)$ from that observed after a storage period of 180 days $\left(17.25 \mathrm{mg} \mathrm{N} .100 \mathrm{~g}^{-1}\right)$. TVBN is a marker of fish quality and freshness. Increased levels of TVBN indicate 


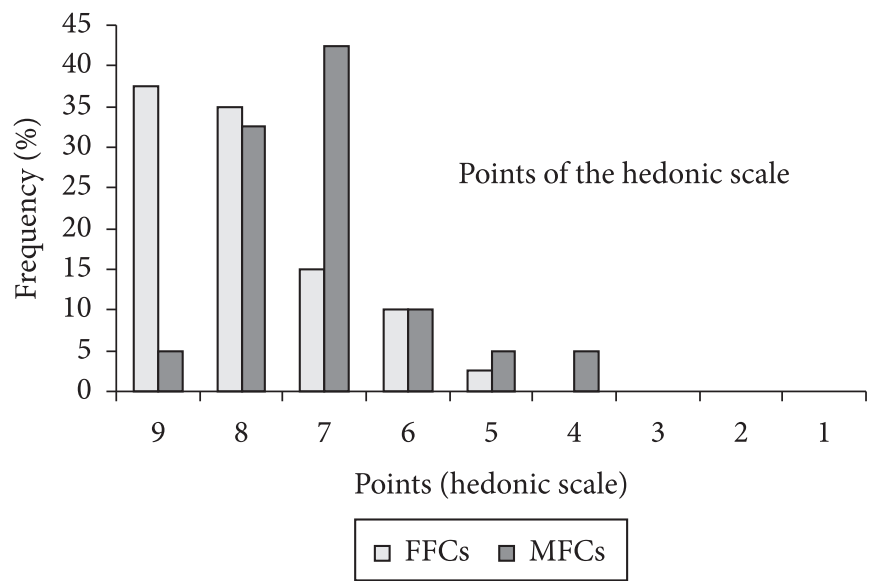

Figure 3. Distribution of general acceptability scores for the fried fish (FFCs) and the microwaved (MFCs) crackers ( 1 = disliked very much; $9=$ liked very much).

spoilage by either bacterial or enzymatic degradation. Although this parameter is not usually applied to fish products other than fresh fish, a low TVBN value (TVBN ranging from 10 to $20 \mathrm{mg} \mathrm{N} .100 \mathrm{~g}^{-1}$ is usually found in fresh fish) indicates good manufacturing practice.

With regard to the microbiological parameters, the fish crackers produced in the present study complied, throughout the storage period, with the requirements of the Brazilian legislation (BRASIL, 1978; 2005) presenting the following

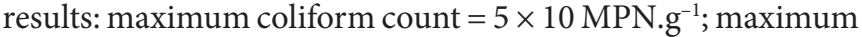
sulfite-reducing clostridia count $=2 \times 10 \mathrm{MPN} \cdot \mathrm{g}^{-1}$; maximum Staphylococcus aureus count $=2 \times 10^{2}$ colony-forming units/g; Salmonella/25 g = absent; and maximum mold and yeast $=10^{3}$ colony-forming units/g (Table 6).

\section{Conclusions}

The development of sensory acceptable fish crackers (made from low-value fish species) of high nutritional value can be a strategy to increase fish consumption and, at the same time, an adjuvant strategy to improve the quality of the diet of children and adolescents by providing a low-fat, low-calorie food product (crackers) that is accepted worldwide. Dried, non-expanded fish crackers that can be stored for as long as 180 days and remain unaltered with regard to physicochemical and microbiological parameters were developed. Consumers can expand the product at home, either by deep frying or by microwave baking using a popcorn-type package. The comparison between FFCs and MFCs showed that the latter should be preferred over the former since MFCs presented lower fat content and contained longchain omega-3 fatty acids. This is the first study describing the use of a popcorn-type package to expand fish crackers.

\section{Acknowledgements}

The authors The authors are grateful for the financial support provided by the foundations FAPESP (Brazil),FAPESP "Fundação de Amparo à Pesquisa do Estado de São Paulo" (process \# 05/59119-0) and to CNPq "Conselho Nacional de Desenvolvimento Científico e Tecnológico" for the grant provided to Bastos.

\section{References}

ANDERSON, G. J.; CONNOR, W. E. On the demonstration of $\omega-3$ essential fatty acid deficiency in humans. American Journal of Clinical Nutrition, v. 49, p. 585-587, 1989.

ANTONACOPOULOS, N.; VYNCKE, W. Determination of volatile basic nitrogen: a third collaborative study by The West European Fish Technologists Association (WEFTA). Zeitschrift für Lebensmittel-Untersuchung und -Forschung, v. 189, p. 309-316, 1989. http://dx.doi.org/10.1007/BF01683206

ASSOCIATION OF THE OFFICIAL ANALYTICAL CHEMISTS AOAC. Official methods of analysis of the Association of Official Analytical Chemists. 16. ed. Maryland: AOAC, 1995.

ÁVILA-DA-SILVA, A. O. et al. Produção pesqueira marinha do Estado de São Paulo. São Paulo, 2005. p. 1-40. (Série Relatórios Técnicos, n. 20).

BADRIE, N.; MELLOWES, W. A. Soybean flour/oil and wheat bran effects on characteristics of cassava (Manihot esculenta Crantz) flour extrudate. Journal Food Science, v. 57, p. 108-111, 1992. http:// dx.doi.org/10.1111/j.1365-2621.1992.tb05435.x

BJERREGAARD, L. J. et al. Fish intake and acute coronary syndrome. European Heart Journal, v. 31, n. 1, p. 29-34, 2010. PMid:19755403. http://dx.doi.org/10.1093/eurheartj/ehp375

BLIGH, E. G; DYER, W. J. A rapid method of total lipid Extraction and Purification. Canadian Journal of Biochemistry and Physiology v. 37, n. 8, p. 911-917, 1959. http://dx.doi.org/10.1139/059-099

BRASIL. Ministério da Saúde. Agência Nacional de Vigilância Sanitária - ANVISA. Resolução - CNNPA n. ${ }^{\circ} 12$, de 1978. Normas técnicas especiais para biscoitos e bolachas. Diário Oficial da República Federativa do Brasil, Poder Executivo, Brasília, DF, 24 jul. 1978. Disponível em: <http://www.anvisa.gov.br/e-legis/>. Acesso em: 24 jan. 2008.

BRASIL. Ministério da Saúde. Agência Nacional de Vigilância Sanitária - ANVISA. Resolução - RDC n 263, de 22 de setembro de 2005. Regulamento técnico para produtos de cereais, amidos, farinhas e farelos. Diário Oficial da República Federativa do Brasil, Poder Executivo, Brasília, DF, 23 set. 2005. Disponível em: <http://e-legis. anvisa.gov/>. Acesso em: 24 jan. 2008.

CODEX STANDARD FOR HONEY. CODEX STAN 222-2001. Norma del Codex para galletas de pescado marino y de agua dulce y de mariscos, crustáceos y moluscos. Codex Standard For Honey, 2001. 5 p.

CHEOW, C. S. et al. Relationship between physicochemical properties of starches and expansion of fish cracker 'keropok'. Journal of Food Quality, v. 27, p. 1-12, 2004. http://dx.doi. org/10.1111/j.1745-4557.2004.tb00633.x

CHEOW, C. S. et al. Effect of fish, starch and salt contents on the microstructure and expansion of fish crackers ('keropok'). Journal of the Science of Food and Agriculture, v. 79, p. 879-885,1999b. http:// dx.doi.org/10.1002/(SICI)1097-0010(19990501)79:6\%3C879::AIDJSFA295\%3E3.3.CO;2-G

CHEOW, C. S. et al. Effect of salt, sugar and monosodium glutamate on the viscoelastic properties of fish cracker ("keropok") gel. Journal of Food Processing and Preservation, v. 23, p. 21-37, 1999a. http:// dx.doi.org/10.1111/j.1745-4549.1999.tb00367.x

DOWNES, F. P; ITO, K. Compedium of methods for the microbiological examination of foods. 4. ed. Washington: American Public Health Association, 2001.

FOOD AND AGRICULTURE ORGANIZATION OF THE UNITED NATIONS - FAO; WORLD HEALTH ORGANIZATION - WHO. Minced Fish. (Torry Advisory Notes, n. 79). Disponível em: $<$ http:// www.fao.org/wairdocs/tan/x5950E/x5950e00.htm>. Acesso em: 23 jul. 2010. 
FOOD AND AGRICULTURE ORGANIZATION OF THE UNITED NATIONS - FAO; WORLD HEALTH ORGANIZATION - WHO. Protein Quality Evaluation. Bethesda, 1989. Report of a joint FAO/ WHO Expert Consultation.

FOOD AND AGRICULTURE ORGANIZATION OF THE UNITED NATIONS - FAO; WORLD HEALTH ORGANIZATION - WHO; ORGANIZAÇÃO DAS NAÇÕES UNIDAS - ONU. Energy and Protein requirements. Geneva: World Health Organization, 1985. Technical Rep. Ser. 724. Report of a joint FAO/WHO/UNU Expert Consultation.

KING, A. M. Development and sensory acceptability of crackers made from the big-eye fish (Brachydeuterus auritus). Food and Nutrition Bulletin, v. 23, p. 317-320, 2002.

KRIS-ETHERTON, P. M. et al. Omega-3 Fatty Acids and Cardiovascular Disease, New Recommendations from the American Heart Association. Arteriosclerosis, Thrombosis and Vascular Biology, v. 23, p. 151- 152, 2003. PMid:12588750. http://dx.doi. org/10.1161/01.ATV.0000057393.97337.AE

KYAW, Z. Y. et al. Effect of steaming time on the linear expansion of fish crackers ('keropok'). Journal of the Science of Food and Agriculture, v. 79, p. 1340-1344, 1999. http://dx.doi. org/10.1002/(SICI)1097-0010(199908)79:11\%3C1340::AIDJSFA352\%3E3.0.CO;2-C

KYAW, Z. Y. et al. Effect of fish to starch ratio on viscoelastic properties and microstructure of fish cracker ('keropok') dough. International Journal of Food Science and Technology, v. 36, p. 741-747, 2001a. http://dx.doi.org/10.1046/j.1365-2621.2001.00481.x

KYAW, Z. Y. et al. The effect of pressure cooking on the microstructure and expansion of fish cracker ('keropok'). Journal of Food Quality, v. 24, p. 181-194, 2001b. http://dx.doi.org/10.1111/j.1745-4557.2001. tb00601.x

LEVITAN, E. B. et al. Fish consumption, marine omega-3 fatty acids, and incidence of heart failure: a population-based prospective study of middle-aged and elderly men. European Heart Journal, v. 30, n. 12, p. 1495-1500, 2009. PMid:19383731. PMCid:2695952. http:// dx.doi.org/10.1093/eurheartj/ehp111

MOHAMED, S. et al. Physical-Properties of Keropok (Fried Crisps) in Relation to the Amylopectin Content of the Starch Flours. Journal of the Science of Food and Agriculture, v. 49, p. 369-377, 1989. http://dx.doi.org/10.1002/jsfa.2740490312

SALLEH, N. M. et al. Objective and subjective hardness of a test item used for evaluating food mixing ability. Journal of Oral Rehabilitation, v. 34, p. 174-183, 2007. PMid:17302945. http:// dx.doi.org/10.1111/j.1365-2842.2006.01645.x

SHAH, A. J. et al. Fish crackers (keropok) produced by extrusion with addition of whey protein concentrate. Food Australia, v. 51, p. 104-106, 1999.
SIMOPOULOS, A. P. et al. Essentiality and recommended dietary intakes for omega- 6 and omega- 3 fatty acids. Annals of Nutrition and Metabolism, v. 43, p. 127-130, 1999. PMid:10436312. http:// dx.doi.org/10.1159/000012777

SINGHAL, R. S. et al. Industrial production, processing, and utilization of sago palm-derived products. Carbohydrate Polymers, v. 72, p. 1-20, 2008. http://dx.doi.org/10.1016/j.carbpol.2007.07.043

SPACKAMAN, D. C. et al. Authomatic recording apparatus for use in the chromatography of aminoacids. Analytical Biochemistry, v. 30, p. 1190-1206, 1958.

SPIES, J. R. Determination of tryptophan in proteins. Analytical Chemistry, v. 39, p. 1412-1415, 1967. PMid:6073804. http://dx.doi. org/10.1021/ac60256a004

STONE, H.; SIDEL, J. L. Sensory Evaluation Practices. 2. ed. San Diego: Academic Press, 1993.

SUBBA, D. Acceptability and nutritive value of keropok-like snack containing meat offal. International Journal of Food Science and Technology, v. 37, p. 681-685, 2002. http://dx.doi.org/10.1046/ j.1365-2621.2002.00600.x

TARLADGIS, B. G. et al. A distillation method for the quantitative determination of malonaldehyde in rancid food. Journal of the American Oil Chemistry Society, v. 37, n. 1, p.44- 48, 1960. http:// dx.doi.org/10.1007/BF02630824

TONGDANG, T. et al. Effect of sago starch addition and steaming time on making cassava cracker (keropok). Starch, v. 60, p. 568-576, 2008. http://dx.doi.org/10.1002/star.200800213

VASANTI NAIR, C. K. et al. Effects of frying parameters on physycal changes of tapioca chips during deep-fat frying. International Journal of Food Science and Technology, v. 16, p. 51-58, 1996.

VINCENT, J. F. V. The quantification of crispness. Journal of the Science of Food and Agriculture, v. 78, p. 162-168, 1998. http:// dx.doi.org/10.1002/(SICI)1097-0010(199810)78:2\%3C162::AIDJSFA97\%3E3.0.CO;2-3

YU, S. Y.; LOW, S. L. Utilization of Pregelatinized Tapioca Starch in the Manufacture of A Snackfood, Fish Cracker (Keropok). International Journal of Food Science and Technology, v. 27, p. 593-596, 1992. PMid:21848869. http://dx.doi.org/10.1111/j.1365-2621.1992. tb01227.x

YU, S. Y.; TAN, L. K. Acceptability of Crackers (Keropok) with FishProtein Hydrolysate. International Journal of Food Science and Technology, v. 25, p. 204-208, 1990. PMid:21848869. http://dx.doi. org/10.1111/j.1365-2621.1990.tb01075.x

YU, S. Y., MITCHELL, J. R. and ABDULLAH, A. Production and Acceptability Testing of Fish Crackers (Keropok) Prepared by the Extrusion Method. Journal of Food Technology, v. 16, p. 51-58, 1981. PMid:21848869. http://dx.doi.org/10.1111/j.1365-2621.1981. tb00995.x 